\title{
Seed dormancy of Ochradenus baccatus (Resedaceae), a shrubby species from Arabian desert regions
}

\author{
Arvind Bhatt ${ }^{1} \&$ Félix Pérez-García ${ }^{2}$ \\ 1. Gulf Organization for Research \& Development, P.O. Box: 210162, Doha, Qatar; drbhatt79@gmail.com \\ 2. Departamento de Biología Vegetal, Universidad Politécnica de Madrid, Escuela Universitaria de Ingeniería Técnica \\ Agrícola, Ciudad Universitaria s/n, 28040-Madrid, Spain; felix.perez@upm.es
}

Received 25-VI-2015. C Corrected 22-II-2016. Accepted 17-III-2016.

\begin{abstract}
Ochradenus baccatus is a perennial glycophyte growing in Middle East and it is one of the most important food sources for many animal species in desert regions. The aim of our study was to investigate the effects of seed storage, light, temperature and gibberellic acid $\left(\mathrm{GA}_{3}\right)$ on germination of $O$. baccatus seeds. We also investigated the germination characteristics of $O$. baccatus seeds under different saline concentration and their capability to recover germination once they were transferred to distilled water. Seeds were stored at room temperature $\left(20 \pm 2{ }^{\circ} \mathrm{C}\right)$ and at $-18^{\circ} \mathrm{C}$. Germination tests were conducted at alternating temperatures of $15 / 25$, $20 / 30$ and $25 / 35^{\circ} \mathrm{C}$ in either continuous darkness or photoperiod of 12-h dark/12-h light. To study the effect of $\mathrm{GA}_{3}$ on germination of $O$. baccatus seeds, freshly-collected seeds and stored seeds were soaked for $24 \mathrm{~h}$ in a $\mathrm{GA}_{3}$ water solution $(1 \mathrm{~g} / \mathrm{L})$ before sowing. To assess the salinity tolerance during germination, seeds were germinated under different salinity levels $(100,200$ and $400 \mathrm{mM} \mathrm{NaCl})$. Stored seeds at room temperature and $-18{ }^{\circ} \mathrm{C}$ germinate equally well at different temperature regimes and light conditions. However, freshly matured seeds were not able to germinate even when they were treated with $\mathrm{GA}_{3}$. On the contrary, stored seeds at room temperature and $-18{ }^{\circ} \mathrm{C}$ treated with $\mathrm{GA}_{3}$ increase the final germination percentages. These results indicated that $O$. baccatus seeds have physiological dormancy and they need to be stored in order to break their dormancy. In the present study, one year of storage did not show a significant variation in germination between the two storage conditions assayed. Therefore, further research is needed to know about the maximum storage period for $O$. baccatus seeds under different storage conditions. Very few $O$. baccatus seeds (less than $5 \%$ ) germinated at the tested lowest concentration of $\mathrm{NaCl}$. However, ungerminated seeds were able to germinate when salinity stress was alleviated. In conclusion, $O$. baccatus seeds have physiological dormancy, and seed storage (at room temperature and at $-18^{\circ} \mathrm{C}$ ) for one year is effective for breaking this dormancy. In addition, $O$. baccatus seeds present ability to remain viable in saline conditions and they will be able to germinate once the salinity level decrease. Rev. Biol. Trop. 64 (3): 965-974. Epub 2016 September 01.
\end{abstract}

Key words: seed storage, seed germination, temperature, salinity, desert species, physiological dormancy.

Ochradenus baccatus Delile (Resedaceae) is a perennial shrub that grows on sandy and stony habitats in Middle East (Al-Fredan, 2010). The fleshy fruits of $O$. baccatus contain high water and sugar content, are consumed and dispersed by various frugivores, and is reported to be one of the most important food sources for many animal species in the Arabian desert (Bronstein et al., 2007; Spiegel \& Nathan, 2007; 2011). The green stems of
$O$. baccatus helps leaves in conducting photosynthesis, especially when leaves are weakened after severe drought environment (Abdulfatah, 2004). This species is widely distributed and is found in Ethiopia, Egypt, Libya, Middle East, Iran and extends into Pakistan (Al-Fredan, 2010; Abd El-Wahab, Zaghloul, Kamel, \& Moustafa, 2008; Khan, Al-Qurainy, \& Nadeem, 2012). The medicinal uses of $O$. baccatus have been well documented (Nawash \& Al-Horani, 
2011; Alqasoumi, Soliman, Awaad, \& Donia, 2012); it is also useful in controlling root-knot nematodes, and can be planted as cover plant/ green manure (Oka, Shuker, Tkachi, Trabelcy, \& Gerchman, 2013). Furthermore, due to extreme drought tolerance ability, $O$. baccatus has the potential to be used in urban landscaping (Sudershan, Abo El-Nil, \& Hussain, 2003). $O$. baccatus have also been categorized among the native plant species that could be exploited for landscaping (Global Sustainability Assessment System, 2014).

Seeds of $O$. arabicus exhibit dormancy and have hard seed coats, presence of some inhibitors, low internal hormone content or underdeveloped embryos (Nadeem, Al-Qurainy, Khan, Tarroum, \& Ashraf, 2012). Contrary to this, Suleiman, Bhat, Jacob and Thomas (2011) have shown that $O$. baccatus seeds have high germination without any pretreatment. This result suggests that seeds of this species have not dormancy. In the present study, we investigated if $O$. baccatus does really display some type of seed dormancy. The inability of seeds to germinate in darkness is a trait generally associated with the ability to form a soil seed bank especially for small seeded species from arid regions (Pons, 1991; Kigel, 1995). To study the effect of light on seed germination of $O$. baccatus we tested germination in continuous darkness or $12 \mathrm{hr}$ light/12 hr dark photoperiod. Besides, O. baccatus seeds behave like orthodox (http://data.kew.org/sid/sidsearch. $\mathrm{html}$ ). Considering the multiple values of the species and its tolerance to seed desiccation, ex situ conservation is an appropriate choice to contribute to the long-term conservation of $O$. baccatus seeds. O. baccatus grows on dry soils and colonise arid environments where saline soils are common. Therefore, it is of great interest to study the effects of salt stress on seed germination of $O$. baccatus. It has been shown in a large number of species that an increase in salt concentration usually delays and reduces seed germination (El-Keblawy \& Al-Shamsi, 2008; Guma, Padrón-Mederos, Santos-Guerra, \& Reyes-Betancort, 2010). However, there is a wide range of variability in salt tolerance among species (Khan \& Gulzar, 2003). Moreover, many seeds that are unable to germinate at high saline concentrations might recover the ability to germinate when salinity levels decrease (Zia \& Khan, 2008). The main aims of our study were to investigate: (i) the germination characteristics of fresh and stored seeds of $O$. baccatus at different temperature and light regimes; (ii) the effect of $\mathrm{GA}_{3}$ on the germination of $O$. baccatus seeds, and (iii) the salinity tolerance of $O$. baccatus seeds during germination.

\section{MATERIALS AND METHODS}

Plant material: Ochradenus baccatus reaches up to two meter and grows as bushes (Bronstein et al., 2007). The species produces yellow flowers, followed by whitish berry containing black seeds (Omar, Al-Mutawa, \& Zaman, 2007). The species mainly flowers from December to March in Middle-East (Zohary, 1966). However, Wolfe and Burns (2001) showed that large plants of $O$. baccatus have the ability to flower continuously whereas, smaller plants are reproductive only during the winter (Wolfe \& Burns, 2001). Furthermore, $O$. baccatus is a gynodioecious species, where female individuals are constant in sex expression; however, male individuals exhibit great variation in functional gender (Amer \& Hassan, 2015).

Seed collection and seed storage: Fruits of $O$. baccatus were collected during last week of March 2013 from Shahniya Dukan Road, Doha, Qatar (2528' 90" N - 51 ${ }^{\circ} 48^{\prime} 89^{\prime}$ ” E). The climate of Qatar is hot during summer (April to September), with daytime temperatures as high as $\left(50^{\circ} \mathrm{C}\right)$. Precipitation is scarce (less than $152 \mathrm{~mm}$ annually), and mostly occurs in winter between November to March (Persian Gulf, 2012). Fruits were randomly collected from the whole population to represent genetic diversity. The pulp was removed manually by mashing with hand gloves, and seeds were obtained and stored both at room temperature $\left(20 \pm 2{ }^{\circ} \mathrm{C}\right)$ and in a freezer at $-18{ }^{\circ} \mathrm{C}$. Freshly 
collected seeds were also immediately tested for germination. However, seeds stored at room temperature as well as at $-18{ }^{\circ} \mathrm{C}$ were retrieved separately after one year and tested for germination. Three replicates of 50 seeds each were used to determine the mean seed mass.

Water uptake during seed imbibition: Water uptake capacity was determined during imbibition of freshly collected seeds, seeds stored at room temperature and seeds stored at $-18{ }^{\circ} \mathrm{C}$, three replications of 50 seeds each were weighed and then reweighed after imbibition in distilled water for 12 and $24 \mathrm{~h}$. Percentage of water uptake (mean \pm standard deviation) was calculated as the amount of water taken up relative to initial seed fresh mass (Baskin, Zackrisson, \& Baskin, 2002).

Seed germination trials: To assess the effect of storage temperature and time on germination of $O$. baccatus, germination tests were conducted in incubators (LMS incubators, UK) set at different temperatures 15/25, 20/30 and $25 / 35{ }^{\circ} \mathrm{C}$ in either continuous darkness or photoperiod of 12-h dark/12-h light (the highest temperature for $12 \mathrm{~h}$ in light and the lowest one for $12 \mathrm{~h}$ in dark) (Vargas-Figueroa, DuquePalacio, \& Torres-González, 2015). Incubators were illuminated with a $25-\mathrm{W}$ white fluorescent lamp. The germination was conducted in 9-cm tight-fitting Petri-dishes containing one disk of Whatman No. 1 filter paper, moistened with $10 \mathrm{~mL}$ of distilled water. During the dark treatment, the dishes were wrapped in aluminum foil to prevent any exposure to light. Four replicates of 25 seeds each were used for each treatment. The number of germinated seeds were counted and removed every alternate day for 20 days. A seed was considered to have germinated when the emerging radicle elongated to $2 \mathrm{~mm}$. Seeds incubated under dark conditions were counted after a period of 20 days.

Effect of seed soaking in gibberellic acid on germination: Lots of 100 freshlycollected and stored seeds were soaked for $24 \mathrm{~h}$ at room temperature in a gibberellic acid
(Sigma- Aldrich, UK) solution $\left(\mathrm{GA}_{3}, 1 \mathrm{~g} / \mathrm{L}\right)$ before sowing. After this treatment, pre-treated seeds were tested for germination at alternating temperatures of $20 / 30{ }^{\circ} \mathrm{C}$ under 12 -h dark/12$\mathrm{h}$ light photoperiod (the highest temperature for $12 \mathrm{~h}$ in light and the lowest one for $12 \mathrm{~h}$ in dark) and continuous darkness. Untreated seeds were sown in the same conditions and used as a control.

Effect of salinity on seed germination: To assess the salinity tolerance during germination, seeds stored at room temperature as well as at $-18{ }^{\circ} \mathrm{C}$ were germinated separately under different salinity levels (100, 200 and $400 \mathrm{mM}$ $\mathrm{NaCl}$ ). Four replicates, each of 25 seeds, were used for each treatment. Seeds were germinated in 9-cm diameter Petri dishes and two layers of Whatman No.1 filter paper, moistened with $10 \mathrm{~mL}$ of salt solution. Petri dishes were sealed with parafilm to minimize evaporation and incubated at $20 / 30^{\circ} \mathrm{C}$ in 12 -h dark/12-h light photoperiod (the highest temperature for $12 \mathrm{~h}$ in light and the lowest one for $12 \mathrm{~h}$ in dark) and continuous darkness. Seed germination was recorded as above. Seeds sown under the same conditions but in distilled water were used as control seeds.

Recovery percentage: Non-germinated seeds from the 20-day $\mathrm{NaCl}$ incubation tests were transferred to distilled water, and incubated for additional 20 days at the same incubation temperature. Recovery percentage (RP) was calculated by the following formula: $R P=(a-b / c-b) \times 100$, where $a$ is the number of seeds germinated in $\mathrm{NaCl}$ solution after a 20 -d period, plus those that recovered to germination in distilled water after another 20 -d period, $\mathrm{b}$ is the number of seeds germinated in $\mathrm{NaCl}$ solution after a 20-day period, and $\mathrm{c}$ is the total number of seeds tested (Yang, Dong, \& Huang, 2010). Initial germination was recorded as (b/c) $\mathrm{x} 100$, and final germination as $(\mathrm{a} / \mathrm{c}) \mathrm{x} 100$. For all experiments, final germination percentage (mean value \pm standard deviation) was calculated. The values of final germination percentages were arcsine square-root transformed 
and then subjected to analysis of variance (ANOVA) using SPSS (untransformed data appear in Tables). In all germination trials, the number of empty seeds in each replicate was always excluded when calculating the final germination percentage. Moreover, for seeds soaked in $\mathrm{GA}_{3}$, mean germination time (MGT, mean value in days \pm standard deviation) was calculated. This parameter was determined according to the following formula: MGT $=\Sigma \mathrm{DN} / \Sigma \mathrm{N}$; where $\mathrm{D}$ is the number of days counted from the date of sowing and $\mathrm{N}$ is the number of seeds germinated on day D (Ellis \& Roberts, 1981). The effect of incubation temperatures (three levels), seed storage conditions (three levels) and light conditions (two levels) on the final germination percentage was analyzed by a three-way factorial ANOVA. Similarly, the effect of soaking in $\mathrm{GA}_{3}$ (soaked and not soaked seeds in $\mathrm{GA}_{3}$; two levels), light conditions (two levels) and storage conditions (three levels) on the final germination percentage, was analyzed by a three-way factorial ANOVA. The effect of soaking in $\mathrm{GA}_{3}$ (two levels) and seed storage conditions (two levels) on MGT was analyzed by a two-way factorial ANOVA. The effect of seed incubation in $\mathrm{NaCl}$ solutions of different concentration (four levels) and seed storage conditions (two levels) on the initial and final germination percentage was analyzed by a two-way factorial ANOVA. Where ANOVA indicated a significant effect, a comparison of mean values was carried out through the least significant difference test at 0.05 level of probability.

\section{RESULTS}

Seed water uptake: The mean mass for a lot of 50 seeds was $42.33 \pm 0.72 \mathrm{mg}$ for freshly collected seeds, $44.33 \pm 0.27 \mathrm{mg}$ for seeds stored at room temperature, and 41.00 $\pm 0.82 \mathrm{mg}$ for seeds stored at $-18{ }^{\circ} \mathrm{C}$. O . baccatus seeds imbibed water quickly and after $12 \mathrm{~h}$ of imbibition in distilled water. Seed mass increased by $11.93 \pm 3.07 \%$ for freshly collected seeds, $19.57 \pm 2.26 \%$ for seeds stored at room temperature, and $21.20 \pm 3.69 \%$ for seeds stored at $-18{ }^{\circ} \mathrm{C}$. After $24 \mathrm{~h}$ of imbibition, seed mass increase was $16.63 \pm 2.14 \%, 23.30$ $\pm 2.58 \%$, and $22.80 \pm 3.05 \%$, respectively. Thus, in O. baccatus the seed coat does not prevent absorption of water.

Seed germination trials: Light condition and incubation temperature were not significant $(\mathrm{P}>0.05)$. None of the freshly matured seeds of $O$. baccatus germinated at all temperature regimes and light conditions assayed (Table 1). Germination of stored seeds ranged from $35-54 \%$ for seeds stored at $-18{ }^{\circ} \mathrm{C}$, and from $41 \%$ to $56 \%$ for after-ripening in dry storage independently of light treatment. Seed storage had a highly significant $(\mathrm{P}<0.001)$ effect on seed germination of $O$. baccatus. Considering the two-way interactions, only the interaction between temperature and seed storage condition was significant $(\mathrm{P}=0.038)$, while the three-way interaction was not significant $(\mathrm{P}=0.503)$. The final germination percentage of fresh seeds were significantly lower $(\mathrm{P}<$

TABLE 1

Final germination percentages (mean values \pm standard deviation) of fresh and stored seeds of Ochradenus baccatus Delile at three temperature regimes under two light conditions (12-h light photoperiod and continuous darkness)

\begin{tabular}{ccccccc} 
Temperature & \multicolumn{5}{c}{ Germination $(\% \pm \mathrm{SD})$ by storage conditions } \\
$\left({ }^{\circ} \mathrm{C}\right)$ & \multicolumn{2}{c}{ Fresh seeds } & \multicolumn{2}{c}{$-18{ }^{\circ} \mathrm{C}$} & \multicolumn{2}{c}{ RT } \\
& Light & Dark & Light & Dark & Light & Dark \\
$15 / 25$ & $0 \mathrm{a}$ & $0 \mathrm{a}$ & $43 \pm 7.68 \mathrm{~b}$ & $54 \pm 8.24 \mathrm{~b}$ & $43 \pm 6.56 \mathrm{~b}$ & $41 \pm 5.92 \mathrm{~b}$ \\
$20 / 30$ & $0 \mathrm{a}$ & $0 \mathrm{a}$ & $45 \pm 9.10 \mathrm{~b}$ & $40 \pm 12.32 \mathrm{~b}$ & $56 \pm 4.90 \mathrm{~b}$ & $52 \pm 6.32 \mathrm{~b}$ \\
$25 / 35$ & $0 \mathrm{a}$ & $0 \mathrm{a}$ & $35 \pm 5.92 \mathrm{~b}$ & $40 \pm 6.32 \mathrm{~b}$ & $50 \pm 10.00 \mathrm{~b}$ & $44 \pm 6.32 \mathrm{~b}$ \\
\hline
\end{tabular}

Means within a row followed by the same letter are not significantly different from each other (LSD test, P $>0.05$ ). Seeds were stored at $-18^{\circ} \mathrm{C}$ or at room temperature (RT). 
$0.05)$ than that of stored seeds. There were not significant differences $(\mathrm{P}>0.05)$ between the final germination percentages reached by seeds stored at room temperature and at $-18{ }^{\circ} \mathrm{C}$.

Effect seed soaking in $\mathbf{G A}_{3}$ on germination: The final germination percentages of $O$. baccatus seeds soaked for $24 \mathrm{~h}$ in a $\mathrm{GA}_{3}$ solution $(1 \mathrm{~g} / \mathrm{L})$ were always higher than these of control seeds (Table 2). However, only in seeds incubated under constant darkness were found significant differences for seeds stored at room temperature and seeds stored at $-18^{\circ} \mathrm{C}$. The highest germination percentage reached by stored seeds soaked in $\mathrm{GA}_{3}$ was $84 \%$. The three-way ANOVA showed a significant effect $(\mathrm{P}<0.001)$ of soaking in $\mathrm{GA}_{3}$ and seed storage conditions $(\mathrm{P}<0.001)$ on final germination, whereas the interaction between both factors was not significant $(\mathrm{P}=0.163)$. Light condition had no significant effect $(\mathrm{P}=0.274)$ on seed germination. The interaction between light and seed storage condition, and between $\mathrm{GA}_{3}$ and storage condition were not significant $(\mathrm{P}=$ 0.057 and $\mathrm{P}=0.163$, respectively). The threeway interaction was significant $(\mathrm{P}=0.007)$.
Germination speed (as expressed by MGT) was higher for seed soaked in $\mathrm{GA}_{3}$ than for untreated seeds ( 2.73 vs. 3.21 days), but these differences were only significant $(\mathrm{P}<0.05)$ for seeds stored at room temperature (Table 2). Seed storage condition was not significant $(\mathrm{P}=$ $0.995)$, whereas soaking in $\mathrm{GA}_{3}$ was significant $(\mathrm{P}=0.029)$. The interaction between seed storage condition and soaking in $\mathrm{GA}_{3}$ was not significant $(\mathrm{P}=0.874)$.

Effect of salinity on seed germination: Germination of $O$. baccatus seeds ranged from 0 to $3 \%$ for the different $\mathrm{NaCl}$ concentrations assayed (Table 3 ). However, the seeds were able to germinate once they were transferred to distilled water. Recovery percentages (RP) ranged from 36 to $68 \%$. The highest RP values were reached for $100 \mathrm{mM} \mathrm{NaCl}(52 \%$ for seeds stored at $-18{ }^{\circ} \mathrm{C}$ and $68 \%$ for seed stored at room temperature). Seed storage condition and $\mathrm{NaCl}$ concentration were significant $(\mathrm{P}=$ 0.021 and $\mathrm{P}<0.001$, respectively) for initial germination. However, the interaction between seed storage condition and seed incubation in $\mathrm{NaCl}$ was not significant $(\mathrm{P}=0.135)$. Seed

TABLE 2

Effect of soaking in a gibberellic acid solution $\left(\mathrm{GA}_{3}, 1 \mathrm{~g} / \mathrm{L}\right)$ on the final germination percentages (mean values \pm standard deviation) and mean germination time (MGT, mean in days \pm standard deviation) of fresh and stored seeds of Ochradenus baccatus Delile at $20 / 30^{\circ} \mathrm{C}$ under two light conditions (12-h light photoperiod and continuous darkness)

\begin{tabular}{|c|c|c|c|c|}
\hline \multirow{2}{*}{ Storage condition } & \multicolumn{2}{|c|}{ Germination $(\% \pm \mathrm{SD})$} & \multicolumn{2}{|c|}{ MGT (days \pm SD) } \\
\hline & Without $\mathrm{GA}_{3}$ & With $\mathrm{GA}_{3} \mathrm{P}$ & Without $\mathrm{GA}_{3}$ & With $\mathrm{GA}_{3} \mathrm{P}$ \\
\hline \multicolumn{5}{|l|}{ Fresh seeds } \\
\hline Light & $0 \mathrm{a}$ & $9 \pm 9.12$ a ns & - & $\mathrm{NC}$ \\
\hline Dark & $0 \mathrm{a}$ & $2 \pm 3.46$ a ns & - & - \\
\hline \multicolumn{5}{|l|}{$-18^{\circ} \mathrm{C}$} \\
\hline Light & $45 \pm 9.10 b$ & $59 \pm 7.14 \mathrm{~b} \mathrm{~ns}$ & $3.24 \pm 0.58 \mathrm{a}$ & $2.69 \pm 0.32 \mathrm{ans}$ \\
\hline Dark & $40 \pm 12.32 b$ & $84 \pm 8.94 \mathrm{~b} * * *$ & - & - \\
\hline \multicolumn{5}{|l|}{ RT } \\
\hline Light & $56 \pm 4.90 \mathrm{~b}$ & $67 \pm 1.14 \mathrm{~b} \mathrm{~ns}$ & $3.21 \pm 0.26 \mathrm{a}$ & $2.73 \pm 0.06 \mathrm{a} *$ \\
\hline Dark & $52 \pm 6.32 \mathrm{~b}$ & $84 \pm 11.66 b^{*}$ & - & - \\
\hline
\end{tabular}

Mean values in a column followed by the same letter are not significantly different from each other (LSD test, P $>0.05$ ). MGT was not calculated (NC) when germination was equal to or less than $10 \%$ and for trials in continuous darkness because the number of germinated seeds was only counted at the end of germination period. P: For each seed storage condition and light condition, significance level between the final germination percentages reached by seeds soaked and non-soaked in $\mathrm{GA}_{3} . * * * \mathrm{P}<0.001 ; * \mathrm{P}<0.05 ; \mathrm{ns}$, not significant.

Seeds were stored at $-18^{\circ} \mathrm{C}$ or at room temperature (RT). 
TABLE 3

Germination percentages (mean values \pm standard deviation) of Ochradenus baccatus Delile seeds stored at $-18{ }^{\circ} \mathrm{C}$ or at room temperature (RT) after incubation in different $\mathrm{NaCl}$ concentrations for 20 days at 20/30 ${ }^{\circ} \mathrm{C}$ under $12-\mathrm{h}$ light photoperiod (initial germination), and germination percentages when non-germinated seeds were incubated for another 20 days in distilled water (final germination)

\begin{tabular}{ccccccc}
$\mathrm{NaCl}$ & \multicolumn{5}{c}{$-18^{\circ} \mathrm{C}$} \\
concentration $(\mathrm{mM})$ & Initial germination & Final germination & RP & Initial germination & Final germination & RP \\
0 (control) & $45 \pm 9.10 \mathrm{~b}$ & $45 \pm 9.10 \mathrm{a}$ & - & $56 \pm 4.90 \mathrm{~b}$ & $56 \pm 4.90 \mathrm{ab}$ & - \\
100 & $0 \mathrm{a}$ & $52 \pm 8.94 \mathrm{a}$ & $52 \pm 8.94 \mathrm{a}$ & $3 \pm 3.32 \mathrm{a}$ & $69 \pm 10.34 \mathrm{~b}$ & $68 \pm 11.74 \mathrm{~b}$ \\
200 & $0 \mathrm{a}$ & $37 \pm 3.32 \mathrm{a}$ & $37 \pm 3.32 \mathrm{a}$ & $0 \mathrm{a}$ & $56 \pm 7.48 \mathrm{ab}$ & $56 \pm 7.48 \mathrm{ab}$ \\
400 & $0 \mathrm{a}$ & $36 \pm 5.66 \mathrm{a}$ & $36 \pm 5.66 \mathrm{a}$ & $0 \mathrm{a}$ & $37 \pm 5.20 \mathrm{a}$ & $37 \pm 5.20 \mathrm{a}$ \\
\hline
\end{tabular}

Means within a column followed by the same letters are not significantly different (LSD test, P $>0.05$ ). Control: seeds incubated for 20 days in distilled water. RP: recovery percentage.

storage condition and $\mathrm{NaCl}$ concentration were significant $(\mathrm{P}=0.001$ and $\mathrm{P}<0.001$, respectively) for final germination, and the interaction was not significant $(\mathrm{P}=0.170)$.

\section{DISCUSSION}

Fresh matured seeds of $O$. baccatus (which have a fully developed embryo) are dormant at maturity and are unable to germinate under different temperature and light conditions. However, the seed coat of $O$. baccatus seeds (fresh as well as stored) is permeable to water as seeds imbibed water quickly after $24 \mathrm{~h}$. Therefore, these seeds do not exhibit physical dormancy, according to the classification system of Baskin and Baskin (2004), where physical dormancy is defined as the result of a water-impermeable layer in the seed or fruit. In addition, $O$. baccatus seeds reached germination percentages up to $56 \%$ and $\mathrm{GA}_{3}$ improved germination depending on temperature and light conditions. Based on the results, we concluded that these seeds have physiological dormancy. Moreover, the breaking of seed dormancy during dry storage (after-ripening) could indicate that the level of physiological dormancy is non-deep (Baskin \& Baskin, 2004). Our results are in contradiction with those obtained by Suleiman, Bhat, Jacob and Thomas (2011) for this same species. These authors found that $O$. baccatus seeds reached high germination percentages without any pretreatment. Probably, the species showed inter-population variation in seed dormancy, and/or variability in germination capacity, depending on the time of seed collection.

The presence of physiological dormancy in freshly matured seeds might allow them time for dispersal and prevents immediate germination at the time of seed release (Kucera, Cohn, \& Leubner-Metzger, 2005; Finch-Savage \& Leubner-Metzger, 2006). The seeds of $O$. baccatus matured in late March, when temperature increases and the chances of rainfall are very low. This suggests that seeds enter to the soil seed bank and remain dormant during unsuitable ecological conditions, when the probability of seedling survival is low (Black, Bewley, \& Halmer, 2006; Soares-Oliveira, Cleiton-José, Monteiro-Ribeiro, \& Rocha-Faria, 2015), as chances of rainfall during summer are minimal (Böer, 1997). Furthermore, the seeds might remain dormant in natural conditions until the winter (November to March). This strategy ensures that germination is unlikely to take place under natural environmental conditions until November (before the onset of winter rain), when conditions for seedling establishment are more favorable. These findings are supported by Wolfe and Burns (2001), who showed that seeds of $O$. baccatus produced in winter have higher germination percentage due to favorable environmental conditions for germination and seedling establishment. In the present study, $O$. baccatus seeds germination was as much as $56 \%$ after one year of dry 
storage (after-ripening) indicating that they are tolerant to desiccation. The poor germination by freshly harvested seeds could also be interpreted as avoiding germination in summer desert conditions.

Seed stored at room temperature and $-18{ }^{\circ} \mathrm{C}$ germinated equally well at the different temperatures assayed. This wide temperature range perhaps allows them to germinate in winter (November to February) in their natural habitat (monthly average temperature between November to February vary between 22.5 to $25.9{ }^{\circ} \mathrm{C}$ - Islam, Kubo, Ohadi, \& Alili, 2009). On the basis of our results, we can confirm that $O$. baccatus seeds became physiologically dormant during maturation. Therefore, seed storage (at room temperature and at $-18{ }^{\circ} \mathrm{C}$ ) for one year worked more effectively in breaking the dormancy of $O$. baccatus seeds. Besides, there was no significant variation in seed germination between the two storage conditions tested. It has been indicated that viability of orthodox seeds could be maintained by drying them in low moisture content at relatively lower temperature (Nahuel-Morandini, MabelGiamminola, \& De Viana, 2013), and their longevity can be extended with reductions in both moisture content and temperature over a wide range of storage environments (http://data.kew. org/sid/sidsearch.html). Our results showed that $O$. baccatus seeds could be stored without significant loss of viability. This was further confirmed by the requirements of after ripening before their germination. However, further investigations are required in order to know the maximum seed storage period for $O$. baccatus under different storage conditions.

Germination of freshly matured seeds treated with $\mathrm{GA}_{3}$ is less than $10 \%$. However, application of $\mathrm{GA}_{3}$ treatments significantly enhanced the germination percentage of stored seeds. We assumed that stored seeds might have reached a maximum release of dormancy after storage and therefore they showed better germination compared to freshly harvested seeds. These findings further support that freshly harvested seeds of $O$. baccatus have physiological dormancy and need after-ripening to remove the dormancy, because the seeds have endogenous dormancy, that might be associated with the physiological maturity of embryos that caused lower germination in freshly matured seeds, even with the application of $\mathrm{GA}_{3}$ (Schütz, Milberg, \& Lamont, 2002; Gao, Jordan, \& Avele, 2012). The final germination percentages of stored seeds of $O$. baccatus treated with $\mathrm{GA}_{3}$ were higher than the control seeds (untreated seeds). However, seeds incubated under constant darkness showed significantly higher germination as compared to light incubated seeds. As the seeds of $O$. baccatus are neutrally photoblastic, it might be possible that the application of $\mathrm{GA}_{3}$ improved the germination of both light and dark incubated seeds. However, higher germination for dark incubated seeds could indicate the biosynthesis of gibberellins (mediated through the phytochrome system) may have been inhibited by light exposure (Kato-Noguchi, 2002).

Very few seeds (less than $5 \%$ ) were able to germinate at the lowest concentration of $\mathrm{NaCl}$ tested. However, once transferred to the distilled water, they were able to germinate. Although the germination recovery was higher for seeds exposed to the lowest concentration of $\mathrm{NaCl}$. These results indicate that although, $O$. baccatus has been categorized as a glycophyte, seeds have ability to remain viable in saline conditions and are able to germinate once the salinity level decreases by rain. Similar results have been obtained for several glycophyte species (El- Keblawy, Al-Ansari, \& Al-Shamsi, 2011). This strategy might help them to form a persistent soil seed bank even in saline habitats that can avoid the vulnerability of local extinction when vegetation on the ground is removed and would be important in restoration conservation of plants (Bakker, Poschlod, Strykstra, Bekker, \& Thompson, 1996). Bajji, Kinet and Lutts (2002) reported that soil seed bank has the ability to remain quiescent at a high salt level, and to germinate immediately after salinity reduction. This is common for both halophytes and other species that colonize similar environments. Results of the present study indicate that seeds of the glycophytic $O$. 
baccatus, like those of the halophyte species, recover their germination when transferred from saline solutions to distilled water.

In conclusion, seeds stored at room temperature and at $-18{ }^{\circ} \mathrm{C}$ germinate equally well under different temperature regimes and light conditions. O. baccatus seeds have physiological dormancy and need to be stored in order to break their dormancy. Considering the tolerance to seed desiccation, ex situ conservation is an appropriate choice to contribute to the longterm seed conservation of $O$. baccatus. Seeds of the species are able to remain viable in saline conditions and they will be able to germinate once the salinity level decreases due to rainfall. $O$. baccatus colonise arid environments where saline soils are common; therefore, the species could be used in plant restoration programs and in revegetation projects in arid coastal areas.

\section{ACKNOWLEDGMENTS}

This work was supported by a grant from the Qatar National Research Fund, QNRF (Grant \# 5-260-1-053). The authors would like to acknowledge Yousef Al Horr, Esam Elsarrag (Gulf Organization for Research and Development) and Ali A. El-Keblawy (Dept of Applied Biology, Faculty of Science and Sharjah Research Academy, University of Sharjah, Sharjah, UAE) for their unlimited support. We also thank Syd Ramdhani, (University of KwaZulu Natal) for his critical revision of a final version of the manuscript.

\section{RESUMEN}

Dormición de semillas de Ochradenus baccatus (Resedaceae), una especie arbustiva de las regiones desérticas arábicas. Ochradenus baccatus es un glicófito perenne que crece en oriente Medio y es una de las fuentes de alimentación más importantes para muchas especies animales de regiones desérticas. El objetivo de nuestro estudio fue investigar los efectos del almacenamiento de semillas, luz, temperatura y ácido giberélico $\left(\mathrm{GA}_{3}\right)$ en la germinación de semillas de $O$. baccatus. También se ha investigado la germinación de semillas de O. baccatus bajo diferentes concentraciones salinas y su capacidad para recuperar la germinación una vez que fueron transferidas a agua destilada. Las semillas se conservaron a temperatura ambiente $\left(20 \pm 2{ }^{\circ} \mathrm{C}\right)$ y a $-18{ }^{\circ} \mathrm{C}$. Los ensayos de germinación se realizaron a temperaturas alternas de 15/25, 20/30 y $25 / 35{ }^{\circ} \mathrm{C}$ bajo oscuridad continua o fotoperiodo de 12-h oscuridad/12-h luz. Para estudiar el efecto del GA en la germinación de semillas de $O$. baccatus, semillas recién recolectadas y semillas almacenadas se sumergieron durante $24 \mathrm{~h}$ en una solución acuosa de $\mathrm{GA}_{3}(1 \mathrm{~g} / \mathrm{L})$ antes de la siembra. Para evaluar la tolerancia a la salinidad durante la germinación, la semillas fueron germinadas bajo diferentes niveles de salinidad (100, 200 y $400 \mathrm{mM}$ $\mathrm{ClNa}$ ). Las semillas conservadas a temperatura ambiente y a $-18{ }^{\circ} \mathrm{C}$ germinaron igualmente bien en los diferentes regímenes de temperatura y condiciones de iluminación. Sin embargo, las semillas recién maduradas fueron incapaces de germinar incluso cuando se trataron con $\mathrm{GA}_{3}$. Por el contrario, las semillas almacenadas tratadas con $\mathrm{GA}_{3}$ incrementaron los porcentajes finales de germinación. Estos resultados indican que las semillas de O. baccatus tienen dormición físiológica y necesitan ser almacenadas para romperla. En este estudio, un año de conservación no supuso una variación significativa en la germinación entre las dos condiciones de conservación ensayadas. Por lo tanto, se precisan investigaciones adicionales para conocer cuáles son los periodos máximos de almacenamiento de semillas de $O$. baccatus bajo diferentes condiciones de conservación. Muy pocas semillas de $O$. baccatus (menos del $5 \%$ ) germinaron a la concentración más baja de ClNa. Sin embargo, las semillas no germinadas fueron capaces de germinar cuando el estrés salino fue aliviado. En conclusión, las semillas de $O$. baccatus tienen dormición fisiológica y el almacenamiento de las mismas (a temperatura ambiente y a $-18{ }^{\circ} \mathrm{C}$ ) durante un año es eficaz para romper dicha dormición. Además, las semillas de O. baccatus presentan capacidad para permanecer viables en condiciones salinas y serán capaces de germinar una vez que el nivel de salinidad disminuya.

Palabras clave: almacenamiento de semillas, germinación de semillas, temperatura, salinidad, especies de desierto, dormición fisiológica.

\section{REFERENCES}

Abd El-Wahab, R. H., Zaghloul, M. S., Kamel, W. M., \& Moustafa, A. R. A. (2008). Diversity and distribution of medicinal plants in North Sinai, Egypt. African Journal of Environmental Science and Technology, 2, 157-171.

Abdulfatah, H. A. (2004). Ecological anatomy of xerophytic leaves from Qatar. Journal of King Saud University - Science, 16, 19-29.

Al-Fredan, M. A. (2010). Sexual polymorphism in the dioecious plant species of eastern Saudi Arabia. International Journal of Plant Reproductive Biology, 2, 85-91. 
Alqasoumi, S. I., Soliman, G. A. E. H., Awaad, A. S., \& Donia, A. E. R. M. (2012). Anti-inflammatory activity, safety and protective effects of Leptadenia pyrotechnica, Haloxylon salicornicum and Ochradenus baccatus in ulcerative colitis. Phytopharmacology, 2, 58-71.

Amer, W. M., \& Hassan, R. A. (2015). Pollen diversity among the inconstant male Ochradenus baccatus Delile populations in Egypt. International Journal of Biosciences, 6, 57-65.

Bajji, M., Kinet, J. M., \& Lutts, S. (2002). Osmotic and ionic effects of $\mathrm{NaCl}$ on germination, early seedling growth, and ion content of Atriplex halimus (Chenopodiaceae). Canadian Journal of Botany, 80, 297-304.

Bakker, J. P., Poschlod, P., Strykstra, R. J., Bekker, R. M., \& Thompson, K. (1996). Seed banks and seed dispersal: important topics in restoration ecology. Acta Botanica Neerlandica, 45, 461-490.

Baskin, J. M., \& Baskin, C. C. (2004). A classification system for seed dormancy. Seed Science Research, $14,1-16$.

Baskin, C. C., Zackrisson O., \& Baskin, J. M. (2002). Role of warm stratification in promoting germination of seeds of Empetrum hermaphroditum (Empetraceae), a circumboreal species with a stony endocarp. American Journal of Botany, 89, 486-493.

Black, M., Bewley, J. D., \& Halmer, P. (2006). The encyclopedia of seeds science, technology and uses. Wallingford: CAB International.

Böer, B. (1997). An introduction to the climate of the United Arab Emirates. Journal of Arid Environments, 35, 3-16.

Bronstein, J. L., Izhaki, I., Nathan, R., Tewksbury, J. J., Spiegel, O., Lotan, A., \& Altstein, O. (2007). Fleshyfruited plants and frugivores in desert ecosystems. Seed dispersal: theory and its application in a changing world. Wallingford: Cab International.

El-Keblawy, A., Al-Ansari, F., \& Al-Shamsi, N. (2011). Effects of temperature and light on salinity tolerance during germination in two desert glycophytic grasses, Lasiurus scindicus and Panicum turgidum. Grass and Forage Science, 66, 173-182.

El-Keblawy, A., \& Al-Shamsi, N. (2008). Effects of salinity, temperature and light on seed germination of Haloxylon salicornium, a common perennial shrub of the Arabian deserts. Seed Science and Technology, $36,679-688$.

Ellis, R. H., \& Roberts, E. H. (1981). The quantification of ageing and survival in orthodox seeds. Seed Science and Technology, 9, 373-409.
Finch-Savage, W. E., \& Leubner-Metzger, G. (2006). Seed dormancy and the control of germination. New Phytologist, 171, 501-523.

Gao, F., Jordan, M. C., \& Ayele, B. T. (2012). Transcriptional programs regulating seed dormancy and its release by after-ripening in common wheat (Triticum aestivum L.). Plant Biotechnology Journal, 10, 465-476.

Global Sustainability Assessment System. (2014). An overview. Doha, Qatar: Gulf Organization for Research and Development.

Guma, I. R., Padrón_Mederos, M. A., Santos-Guerra, A., \& Reyes-Betancort, J. A. (2010). Effect of temperature and salinity on germination of Salsola vermiculata $\mathrm{L}$. (Chenopodiaceae) from Canary Islands. Journal of Arid Environments, 74, 708-711.

Islam, M. D., Kubo, I., Ohadi, M., \& Alili, A. A. (2009). Measurement of solar energy radiation in Abu Dhabi, UAE. Applied Energy, 86, 511-515.

Kato-Noguchi, H. (2002). Effects of red light on gibberellin 3Phydroxylase gene expression in dark-grown seedlings of dwarf and tall cultivars of Pisum sativum. Journal of Plant Physiology, 159, 107-612.

Khan, S., Al-Qurainy, F., \& Nadeem, M. (2012). Biotechnological approaches for conservation and improvement of rare and endangered plants of Saudi Arabia. Saudi Journal of Biological Sciences, 19, 1-11.

Khan, M. A., \& Gulzar, S. (2003). Light, salinity and temperature effects on the seed germination of perennial grasses. American Journal of Botany, 90, 131-134.

Kigel, J. (1995). Seed germination in arid and semiarid regions. In J. Kigel, \& G. Galili (Eds.). Seed development and germination (pp. 645-699). New York: Marcel Dekker.

Kucera, B., Cohn, M. A., \& Leubner-Metzger, G. (2005). Plant hormone interactions during seed dormancy release and germination. Seed Science Research, 15, 281-307.

Nadeem, M., Al-Qurainy, F., Khan, S., Tarroum, M., \& Ashraf, M. (2012). Effect of some chemical treatments on seed germination and dormancy breaking in an important medicinal plant ochradenus arabicus Chaudhary, Hill C. \& AG MILL. Pakistan Journal of Botany, 44, 1037-1040.

Nahuel-Morandini, M., Mabel-Giamminola, E., \& De Viana, M. L. (2013). Tolerancia a la desecación de semillas de Prosopis feroxy Pterogyne nitens (Fabaceae). Revista de Biología Tropical, 61, 335-342.

Nawash, O. S., \& Al-Horani, A. S. (2011). The most important medicinal plants in Wadi Araba desert in South West Jordan: a review article. Advances in Environmental Biology, 5, 418-425. 
Oka, Y, Shuker, S., Tkachi, N., Trabelcy, B., \& Gerchman, Y. (2013). Nematicidal activity of Orchradanus baccatus against the root-knot nematode Meloidogyne javanica. Plant Pathology, 63, 221-231.

Omar, S. A. S., Al-Mutawa, Y., \& Zaman, S. (2007). Vegetation of Kuwait. Kuwait: Kuwait Institute of Scientific Research.

Persian Gulf. (2012). http://www.emecs.or.jp/guidebook/ eng/pdf/07persian.pdf.

Pons, T. L. (1991). Induction of dark dormancy in seeds: its importance for the seed bank in the soil. Functional Ecology, 5, 669-675.

Schütz, W., Milberg, P., \& Lamont, B. B. (2002). Seed dormancy, after-ripening and light requirements of four annual Asteraceae in South-western Australia. Annals of Botany, 90, 707-714.

Soares-Oliveira, T. G., Cleiton-José, A., Monteiro-Ribeiro, L., \& Rocha Faria, J. M. (2015). Longevity and germination of Syagrus romanzoffiana (Arecaceae) seeds and its ecological implications. Revista de Biología Tropical, 63, 333-340.

Spiegel, O., \& Nathan, R. (2007). Incorporating dispersal distance into the disperser effectiveness framework: frugivorous birds provide complementary dispersal to plants in a patchy environment. Ecology Letters, 10, 718-728.

Spiegel, O., \& Nathan, R. (2011). Empirical evaluation of directed dispersal and density-dependent effects across successive recruitment phases. Journal of Ecology, 100, 392-404.
Sudhersan, C., Abo El-Nil, M., \& Hussain, J. (2003). Tissue culture technology for the conservation and propagation of certain native plants. Journal of Arid Environments, 54, 133-147.

Suleiman, M. K., Bhat, N. R., Jacob, S., \& Thomas, R. (2011). Germination studies in Ochradenus baccatus Delile., Peganum harmala L. and Gynandriris sisyrinchium Par. Research Journal of Seed Science, 4, 58-68.

Vargas-Figueroa, J. A., Duque-Palacio, O. L., \& TorresGonzález, A. M. (2015). Germinación de semillas de cuatro especies arbóreas del bosque seco tropical del Valle del Cauca, Colombia. Revista de Biología Tropical, 63, 249-261.

Wolfe, L. M., \& Burns, J. L. (2001). A rare continual flowering strategy and its influence on offspring quality in a gynodioecious plant. American Journal of Botany, $88,1419-1423$.

Yang, X., Dong, M., \& Huang, Z. (2010). Role of mucilage in the germination of Artemisia sphaerocephala (Asteraceae) achenes exposed to osmotic stress and salinity. Plant Physiology and Biochemistry, 48, 131-135.

Zia, S., \& Khan, M. A. (2008). Seed germination of Limonium stocksii under saline conditions. Pakistan Journal of Botany, 40, 683-695.

Zohary, M. (1966). Flora Palaestina (vol. 1). Jerusalem: Israel Academy of Sciences and Humanities. 